\title{
Potential Pollinators of Gossypium hirsutum L.
}

\author{
Pravin J. Kale \\ Assistant Professor, Department of Botany, Narayanrao Kale Smruti Model College, Karanja, Gh.Dist- Wardha442203 (M.S.) India
}

\begin{abstract}
The present investigations are being carried out during the period 2005-2007 at Amravati. In Gossypium hirsutum L. the investigation was done on different aspect of pollination. The plant species were visited daily or on alternate day to record the pollinators activity. The pollen production was found to be $13774.22 \pm 1223.67$ to $15299.69 \pm 1383.88$. The pollen: ovule ratio was found to be 550.96 to 1235.49. The pollen viability was measured to be $93 . \overline{58}$ to $96.54 \%$. The main pollinators were Apisdorsata, Apisflorea, Trigona spp., Halictidae fly and red colour bee (unidentified),thrips, grass hopper, red beetle and ants. The bees were more active during the morning hours i.e. from 09.00 hrs. to 13.30 hrs. In the afternoon the visitor's activity was found to be very less. From 15.30 hrs to 17.30 hrs. The bees visited 1 to 6 flowers in a single bout. The maximum pollen load carried out by A. florea 7245.8- 8445.8. However, less pollen load carried out byTrigonaspp. 442.6-762.3 andHalictidae 493.1-577.4, whereas small size black bee (unidentified) carried out 1831.5 pollen. The effect of different treatments on the yield in terms of dry weight of cotton with seeds was found to be 297.17 to 412.68 gm in self-pollination; 336.58 to $518.16 \mathrm{gm}$ in open-pollination and 379.57 to $637.18 \mathrm{gm}$ in insect-pollination In the present investigation it was found wild pollinator play important role for higher seed yield in G. hirsutum
\end{abstract}

Keywords: Amravati, Gossypium hirsutum L., pollinators, Apis florae, yield

\section{Introduction}

Gossypiumhirsutum is an important fiber yielding plant cultivated in many states of India. It is one of the major cash crops cultivated by the farmers of Vidarbha region of Maharashtra. G. hirsutum is annual or perennial herb with hairy stem, it is commonly known as -Ctron". It is important to study the role of wild pollinators in this crop for higher yield. It is one of the major cash crops of Vidharbha region of Maharashtra. The role of insects as pollinators was first reported by Kolreuter in 1763 . Honey bees are important for effecting qualitative and quantitative improvement in crop yields (Deodikar and Suryanarayana, 1977). India has diverse bee fauna such as Apis species engaged in pollination of economically important plants. Insect pollination can play an important role in maintaining a sustainable and profitable agriculture with minimized disruptions to the environment. Good bee pollination and optimize crop yield are thus part of sound environmental management policy efforts to quantify the value of bee pollination (Delaplane and Mayer, 2000). The present research work was started with the aim to know the flowering phenology and role of insects in general and bees in particular in pollination of the crop G. hirsutum L. cultivated in Vidarbha and thus to enhance the yield of this crop.

\section{Materials and Methods}

The present investigations were being carried out during the period 2005-2007 at Amravati ( $20^{0} 54^{\prime}$ to $20^{\circ} 57^{\prime}$ North Latitude and $77^{\circ} 43^{\prime}$ to $77^{\circ} 48^{\prime}$ East Longitude)situated in Amravati district of Maharashtra State. The observations were taken from three different cultivated fields around Amravati city. The plant species were visited daily or on alternate day for collection data.

Simple method of Nair and Rastogi (1963) was adopted to know the pollen production per anther/ flower. Pollen viability rates were observed with tetrazolium (TTC) test method (Loken, 1942) to determine the pollen viability in vitro. By dividing the number of pollen grains produced per flower by the number of ovules in the flower the pollen: ovule ratio of plants under investigation was obtained (Cruden, 1977). Pollen load carried out by insect was estimated as per method proposed by (Dafni, 1992). The flower visitors were observed for their visit timings at the different study sites during the flowering period of plant. In the initial, peak and final phases of the blooming period, the types and timings of the visitors were noted. The conduct of insect visitors was observed at different hours of the day during the flowering period at each study sites and the activities of the forager during a visit were noted as per method followed by (Tidke, 2005) . Photographs were taken with the help of Digital Camera (Sony Make). .

Mature flower buds were selected, bagged and also tagged with cotton thread at the pedicel to know the mode of reproduction. For each test, hundred flower buds were selected from each plant species. Yield comparison of three different pollination treatments, viz., -SP" (self-pollinated), BP" (insect pollination) and -९P" (open pollination) were done as per the method followed by Panda et al. (1988) and Rao and Suryanarayana (1979).

\section{Results and Discussion}

The present research work was initiated with the aim to know the role of insects in general and bees in particular in pollination of the Gossyipum crop cultivated in Vidarbha and thus to enhance the yield of crops. It was proposed to study the population of pollinators, their activities, behavior and their role in crop pollination.

Bees play important role for higher yield in Gossypium crop (Viviane C. P. et al., 2014). Asia represents a wide variety of

\section{Volume 5 Issue 2, February 2016}




\section{International Journal of Science and Research (IJSR) \\ ISSN (Online): 2319-7064 \\ Index Copernicus Value (2013): 6.14 | Impact Factor (2014): 5.611}

climatic zones and accordingly several kinds of crops are grown; many of these are cross-pollinated and required external agents for pollination for increased fruit/seed production (Sihag, 1995). It is important to study the process of pollination and pollinators in crop plant because more than $80 \%$ of all flowering plants species rely on different animals for pollination (Nabhan and Buchmann, 1997).

According to Vaissiere (1991) cotton flower produces an average of 30,000 to 40,000 pollen grains represent a mass of 19 to $26 \mathrm{mg}$ of fresh pollen. In the present study pollen production was found to be $13774.22+1223.67$ to $15299.69+$ 1383.88 (Table No.1). Stone et al. (1995) pointed out the need for assessing the viability of pollen used in hand pollination experiment. The pollen viability means capacity to live, grow, germinate or develop (Lincoln et al., 1982). In the present investigation, the pollen viability was found to be 93.58 to $96.54 \%$ (Table No. 2).

The pollen:ovule ratio was determined by counting the number of pollen grains produced per flower and divided by the number of ovules per flower (Cruden, 1977). There is a strong correlation between pollen:ovule and breeding system (Cruden, 1977 and Preston, 1986). During present investigation pollen: ovule ratio was found to be 550.96 to 1235.49 (Table No.3).

Stigmas have been studied extensively in plants that exhibit self-incompatibility, a process that restricts inbreeding. Selfincompatible stigmas reject self-pollen by inhibiting pollen hydration, germination, and tube invasion (Wheeler et al., 2001). While doing present investigation thestigma becomes receptive during $09.00 \mathrm{hrs}$. at the time of anther dehiscence. The receptivity ceases during $17.00 \mathrm{hrs}$. to $18.00 \mathrm{hrs}$. After the loss of receptivity stigma became blackish in colour.

During investigation main visitors was found on G.hirsutum flower were Apisdorsata (Plate I Fig. 2), Apisflorea(Plate I Fig.1), Trigona spp., Halictidae fly (Plate I Fig.3) and red colour bee (unidentified) (Plate I Fig.4), which visited the flower regularly. Other visitors were thrips, grasshopper (Plate I Fig.5), red beetle (Plate I Fig.6) and ants. The bees were more active during the morning hours i.e. from $09.00 \mathrm{hrs}$. to $13.30 \mathrm{hrs}$. In the afternoon the visitors activity was found to be very less. From $15.30 \mathrm{hrs}$ to $17.30 \mathrm{hrs}$. again the visitors activities were found to be more. The bees landed on flower to collect the pollen and deposited it in pollen basket. The bees visited 1 to 6 flowers in a single bout. Duration of other visitors visit was casting from 4 seconds to 30 minute (Table No. 4). While by Moffettet al.,(1975) recorded bee spent average 12.5 seconds and visiting time was ranged between 1 to 60 seconds. The thrips and ants resided in the flower for long period. Thrips were reported by Mailhot D. et al., (2007) on cotton plant. Whereas grass hopper and red beetle occasionally visited the flower. Stephen and Shipman (1990) reported A. mellifera as a regular flower visitor in $G$. hirsutum. Pleasants and Wendel (2010) recorded honeybees and carpenter bees are potential pollinators of G. tomentosum and G. hirsutumwhich correlate with present investigation.
The majority of species of flowering plants rely on pollination by insects, so that their reproductive success and in part their population structure are determined by insect behavior. Insects that specialize in visiting flowers have evolved an array of foraging strategies that act to improve their efficiency, which in turn determine the reproductive success of the plants that they visit (Goulson, 1999).

In G.hirsutum flowers are yellowish white, a number of insect species visited the flower. The regular visitors were $A$. dorsata, A.florea, Trigona spp., Halictidae fly and red colour bee. Other visitors were thrips, grass hopper, red beetle and ants. The bees entered vertically downwards in to the flower by putting the ventral side of its body towards anthers. Rarely, the bees foraged in the opposite direction. Inside the flower the bees found it difficult to move from one side to another. $A$. florea entered the flowers vertically downwards by facing its ventral side towards petals. In this way, the front portion of the head and body were covered with pollen when they visited the flowers. Inside the flowers the bees moved freely. A. florea collected both pollen and nectar. The peak population of $A$. florea and Trigona spp. was observed between $09.00 \mathrm{hrs}$ to $17.30 \mathrm{hrs}$. On an average A. florea spent 5 to 120 seconds inside the flower, Trigona spp. spent 4 to 88 seconds, A. dorsata spent 4 to 540 seconds, red colour bee spent 4 to 120 second, Halictidae fly 05 to 1800 seconds inside flowers (Table No. 4). Grass hopper visited the flower rarely. Thrips were usually found in tubular flower to feed on pollen or nectar and also helped in pollination mechanism similar type of observation was found by Neli and Kalita (2013) in pollinator observation on Casealpinia crista.

Many pollen collecting insects harvest pollen from several flowering species. The estimation of pollen load carried by the pollinators is one of the traditional methods of measuring constancy (Dafni, 1992). Priti and Sihag (1997) reported the number of loose pollen grains that adhered to the body of the insect visitors. A. floreacarried out the pollen load $6578.90 \pm$ 755.31, A. dorsatacarried the pollen load $9891.10 \pm 901.13$, A. melliferacarried the pollen load $9002.15 \pm 849.09$ and also reported that maximum number of pollen grains were carried by $A$. dorsata among all the insect visitors. During present investigation the maximum pollen load carried out by $A$. florea 7245.8- 8445.8. However less pollen load carried out byTrigonaspp. 442.6-762.3 andHalictidae 493.1-577.4. Whereas small size black bee (unidentified) carried out 1831.5 pollen (Table No.4).Thrips carried negligible number of pollen grains. It indicates that the pollen grains carried out by insect depend on the size of an insect body. Whereas MohanaRaoet al.(1995) in $G$. hirsutum reported $A$. dorsataand $A$. ceranaindica collecting the maximum pollen from flower.

In present study bees are found to be dominant amongst all foragers. Bees forage on the flower to collect the pollen and nectar. The maximum pollen load was found to be carried out by A. florea as compared to other foragers.

In the present study breeding experiments showed that fruit set in open or natural and insect pollination is always higher,

Volume 5 Issue 2, February 2016 


\section{International Journal of Science and Research (IJSR) \\ ISSN (Online): 2319-7064 \\ Index Copernicus Value (2013): 6.14 | Impact Factor (2014): 5.611}

which is an indication of successful pollination. Pollen:ovule ratio is also served as an index of breeding system. The proportion in which pollen gains and ovules differentiate in an individual reflects the efficiency of pollen transfer among its flowers (Cruden, 1977). It is reported that pollen:ovule ratio more or less reflects the breeding system in all crop plant species. The present observations corroborate with the observations made by Cruden (1977).

During present study the effect of different treatments on the yield in terms of dry weight of cotton with seeds was found to be 297.17 to 412.68 gm in self-pollination; 336.58 to 518.16 gm in open-pollination and 379.57 to $637.18 \mathrm{gm}$ in insectpollination (Table No. 5). Mahadevan and Chandy (1959) reported increase yield by weight 23-34 and 40-53\% respectively in two cultivars plot caged with bees over the exclude bees plot. Sidhu and Singh (1962) compared production in cages with bees with cages without bees they shows 17.45 to $18.98 \%$ increase in caged plot as compared with cages without bees in Gossypiumspp which correlate with present study. Similar type of observation was found in Brassicajuncea which shows higher yield in open pollination and bee pollination over other pollination treatment by Goswami and Khan (2014).

Deodikar and Suryanarayana (1977) roughly estimated the data on yield parameters. The effect of different bee species on yield shows that there is a gradual increase in number of seeds and seed weight per pod in order of A. florea, A. cerana and A. dorsatavisited flowers. Sinha and Chakrabarti (1995) reported the effect of two pollination modes on seed yield and weight. In the present investigation it was found higher seed yield in insect-pollination and open-pollination over self-pollination and hence the wild pollinators play important role for the increase in yield of G. hirsutum.

\section{Conclusions}

The role of insects in general and bees in particular in pollination of the crop plants is of paramount importance for better crop yield. During investigation main visitors was found on G.hirsutum flower were Apisdorsata,Apisflorea,Trigona spp., Halictidae fly and red colour bee (unidentified), which visited the flower regularly. Other visitors were thrips, grasshopper and ants are the potential pollinators G. hirsutum. The bees were more active during the morning hours i.e. from $09.00 \mathrm{hrs}$. to $13.30 \mathrm{hrs}$. In the afternoon the visitors activity was found to be very less. During present study the effect of different treatments on the yield in terms of dry weight of cotton with seeds was found to be 297.17 to $412.68 \mathrm{gm}$ in self-pollination; 336.58 to 518.16 $\mathrm{gm}$ in open-pollination and 379.57 to $637.18 \mathrm{gm}$ in insectpollination hence wild pollinators play important role for the increase in yield of G. hirsutum.

\section{Tables}

Table 1: Pollen production in successive flowers G. hirsutum.

\begin{tabular}{|c|c|c|c|c|c|c|}
\hline Year & Sites & Mean No. of p.g. per flower & S.D. & S.E. & Range & Total pollen production \\
\hline \multirow{4}{*}{ First } & $($ Site-1) & 14162.44 & 6423.69 & 2031.52 & $4459.90-28779.30$ & $14162.44 \pm 6423.69$ \\
\cline { 2 - 7 } & $($ Site-2) & 14536.54 & 1107.76 & 350.33 & $12879.20-16434.40$ & $14536.54 \pm 1107.76$ \\
\cline { 2 - 7 } & $($ Site-3) & 14601.49 & 2009.84 & 635.62 & $14083.10-18704.30$ & $14601.49 \pm 2009.84$ \\
\hline \multirow{4}{*}{ Second } & $($ Site-1) & 13774.22 & 1223.67 & 386.99 & $12088.20-16128.60$ & $13774.22 \pm 1223.67$ \\
\cline { 2 - 7 } & $($ Site-2) & 15815.11 & 1094.96 & 346.28 & $13611.50-17463.70$ & $15815.11 \pm 1094.96$ \\
\cline { 2 - 7 } & $($ Site-3) & 15987.27 & 1243.84 & 393.37 & $14463.80-18305.20$ & $15987.27 \pm 1243.84$ \\
\hline \multirow{3}{*}{ Third } & $($ Site-1) & 14810.95 & 952.13 & 301.11 & $13079.30-16788.20$ & $14810.95 \pm 952.13$ \\
\cline { 2 - 7 } & $($ Site-2) & 14869.13 & 1150.16 & 363.74 & $12889.20-16788.20$ & $14869.13 \pm 1150.16$ \\
\cline { 2 - 7 } & $($ Site-3) & 15299.69 & 1383.88 & 437.66 & $13368.80-1835.20$ & $15299.69 \pm 1383.88$ \\
\hline
\end{tabular}

Table 2: Pollen viability in Gossypiumhirsutum

\begin{tabular}{|c|c|c|c|c|c|c|}
\hline \multirow{2}{*}{ Year } & Site & $\begin{array}{c}\text { Av. No. of } \\
\text { viable pollen }\end{array}$ & $\begin{array}{c}\text { Av. No. of } \\
\text { non viable } \\
\text { pollen }\end{array}$ & $\begin{array}{c}\text { Av.Total } \\
\text { No. of } \\
\text { Pollen }\end{array}$ & $\begin{array}{c}\text { Av.Percentage } \\
\text { of viable } \\
\text { pollen grains }\end{array}$ & Mean \\
\hline \multirow{3}{*}{ First } & Site-1 & 115.14 & 4.22 & 119.36 & 96.41 & 96.41 \\
\cline { 2 - 7 } & Site-2 & 124.86 & 7.04 & 131.9 & 94.588 & 94.59 \\
\cline { 2 - 7 } & Site-3 & 119.96 & 6.89 & 126.85 & 94.553 & 94.55 \\
\hline \multirow{3}{*}{ Second } & Site-1 & 124.86 & 7.04 & 131.9 & 94.588 & 94.59 \\
\cline { 2 - 7 } & Site-2 & 146.76 & 5.13 & 151.89 & 96.539 & 96.54 \\
\cline { 2 - 7 } & Site-3 & 119.52 & 7.66 & 127.18 & 93.582 & 93.58 \\
\hline \multirow{3}{*}{ Third } & Site-1 & 116.44 & 4.89 & 121.33 & 95.202 & 95.2 \\
\cline { 2 - 7 } & Site-2 & 133.3 & 5.13 & 138.43 & 95.627 & 95.63 \\
\cline { 2 - 7 } & Site-3 & 119.52 & 5.56 & 125.08 & 95.21 & 95.21 \\
\hline
\end{tabular}

Volume 5 Issue 2, February 2016 www.ijsr.net 


\section{International Journal of Science and Research (IJSR) ISSN (Online): 2319-7064}

Index Copernicus Value (2013): 6.14 | Impact Factor (2014): 5.611

Table 3: Pollen: ovule ratio in G. hirsutum.

\begin{tabular}{|l|l|c|c|c|}
\hline Year & Site & Total pollen production & No. of ovule & Pollen: ovule ratio \\
\hline First & Site 1 & 14162.44 & 24 & 590.10 \\
& Site 2 & 14536.54 & 25 & 581.46 \\
& Site 3 & 14601.49 & 24 & 608.39 \\
Second & Site 1 & 13774.22 & 25 & 550.96 \\
& Site 2 & 29651.98 & 24 & 1235.49 \\
& Site 3 & 15987.27 & 24 & 666.13 \\
Third & Site 1 & 14810.95 & 24 & 617.12 \\
& Site 2 & 14869.13 & 24 & 619.54 \\
& Site 3 & 15299.69 & 24 & 637.48 \\
\hline
\end{tabular}

Table 4: Visitor censes in G. hirsutum.

\begin{tabular}{|c|c|c|c|c|c|c|c|c|}
\hline \multirow{2}{*}{$\begin{array}{c}\text { Forager } \\
\text { Years }\end{array}$} & \multirow{2}{*}{$\begin{array}{l}\text { Forage } \\
\text { type }\end{array}$} & \multirow{2}{*}{$\begin{array}{c}\text { Length of } \\
\text { visit in sec }\end{array}$} & \multirow{2}{*}{$\begin{array}{c}\text { Time of } \\
\text { visit }\end{array}$} & \multicolumn{3}{|c|}{ Pollen load } & \multirow{2}{*}{$\begin{array}{c}\text { Visit per } \\
\text { bout }\end{array}$} & \multirow{2}{*}{$\begin{array}{c}\text { Visit } \\
\text { frequency }\end{array}$} \\
\hline & & & & First & Second & Third & & \\
\hline \multicolumn{9}{|c|}{ (Site-1) } \\
\hline Trigona spp. & $\mathrm{P}$ & 30-Apr & 09.00-17.30 & 762.3 & \begin{tabular}{|l|l|}
672.6 \\
\end{tabular} & \begin{tabular}{|l|l|}
654.3 \\
\end{tabular} & 5-Mar & $\mathrm{VF}$ \\
\hline A. florea & $\mathrm{P}$ & $05-60$ & |09.00-17.30 & 7840.8 & 7245.8 & 8445.8 & 6-Apr & $\mathrm{VF}$ \\
\hline Halictidae fly & $\mathrm{P}$ & $15-600$ & $09.00-17.30$ & 514.8 & 543.1 & \begin{tabular}{|l|l|}
517.1 \\
\end{tabular} & 4-Feb & $\mathrm{VF}$ \\
\hline A. dorsata & $\mathrm{P}$ & $04-120$ & 09.00-17.30 & - & - & 1831.5 & 5-Mar & $\mathrm{VF}$ \\
\hline R.C.B & $\mathrm{N}$ & May-45 & 09.00-17.30 & - & - & - & 4-Feb & $\mathrm{VF}$ \\
\hline Thrips & $\mathrm{P}$ & Reside & $09.30-17.30$ & - & - & - & 1 & $\mathrm{VO}$ \\
\hline Ants & $\mathrm{N}$ & L. time & $\mid 09.30-17.30$ & - & - & - & 1 & $\mathrm{VF}$ \\
\hline Grass hopper & $\mathrm{F}$ & 20-Jun & $09.30-17.30$ & - & - & - & 1 & VR \\
\hline Red beetle & $\mathrm{F}$ & $03-15$ & $09.30-17.30$ & - & - & - & 1 & $\mathrm{VO}$ \\
\hline \multicolumn{9}{|c|}{ (Site-2) } \\
\hline Trigonaspp. & $\mathrm{P} / \mathrm{N}$ & $05-20$ & $09.00-17.30$ & 648.2 & \begin{tabular}{|l|l|}
442.67 \\
\end{tabular} & \begin{tabular}{|l|l|}
545.5 \\
\end{tabular} & 4-Mar & $\mathrm{VF}$ \\
\hline A. florea & $\mathrm{P} / \mathrm{N}$ & $15-130$ & $\mid 09.00-17.30$ & 7452.7 & \begin{tabular}{|l|l|}
595.8 \\
\end{tabular} & 7892.3 & 6-Feb & $\mathrm{VF}$ \\
\hline Halictidae fly & $\mathrm{P}$ & Oct-90 & $\mid 08.30-17.30$ & 577.4 & \begin{tabular}{|l|l|}
493.1 \\
\end{tabular} & \begin{tabular}{|l|l|}
568.5 \\
\end{tabular} & 4-Feb & VF \\
\hline R.C.B & $\mathrm{P}$ & Apr-55 & $09.00-17.30$ & - & - & - & 1 & $\mathrm{VF}$ \\
\hline Grass hopper & $\mathrm{P}$ & $15-\mathrm{Feb}$ & $\mid 10.00-17.30$ & - & - & - & 1 & $\mathrm{VO}$ \\
\hline Red beetle & $\mathrm{F}$ & Feb-40 & $09.30-17.30$ & - & - & - & 1 & $\mathrm{VO}$ \\
\hline Thrips & $\mathrm{P}$ & Reside & $\mid 09.00-17.30$ & - & - & - & 1 & VF \\
\hline Ants & $\mathrm{N}$ & L.time & 09.30-17.30 & - & - & - & 1 & $\mathrm{VF}$ \\
\hline \multicolumn{9}{|c|}{ (Site-3) } \\
\hline Trigona spp. & $\mathrm{P} / \mathrm{N}$ & 25 -Oct & 09.00-17.30 & 442.6 & \begin{tabular}{|l|l|}
563.57 \\
\end{tabular} & \begin{tabular}{|l|l|}
613.8 \\
\end{tabular} & 5-Mar & $\mathrm{VF}$ \\
\hline A. florea & $\mathrm{P} / \mathrm{N}$ & $08-120$ & $09.00-17.30$ & 7595.8 & \begin{tabular}{|l|l|}
583.3 \\
\end{tabular} & 7458.6 & 4-Feb & $\mathrm{VF}$ \\
\hline Halictidae fly & $\mathrm{P}$ & $15-90$ & $\mid 09.00-17.30$ & 493.1 & \begin{tabular}{|l|l}
541.5 \\
\end{tabular} & \begin{tabular}{|l|l|}
559.2 \\
\end{tabular} & 6-Feb & $\mathrm{VF}$ \\
\hline R.C.B. & $\mathrm{P}$ & $04-120$ & $\mid 09.00-17.30$ & - & - & - & 1 & $\mathrm{VF}$ \\
\hline Grass hopper & $\bar{P}$ & $04-03$ & $10.00-17.30$ & - & - & - & 1 & $\mathrm{VO}$ \\
\hline Red beetle & $F$ & Jun-65 & $10.00-16.30$ & - & - & - & 1 & $\mathrm{VO}$ \\
\hline Thrips & $\mathrm{P}$ & Reside & $\mid 09.00-17.30$ & - & - & - & 1 & $\mathrm{VF}$ \\
\hline Ants & $\mathrm{N}$ & time $03-05$ & $09.00-17.30$ & - & - & - & 1 & VR \\
\hline Grass hopper & $\mathrm{F}$ & 6-May & $\mid 09.00-17.30$ & - & - & - & 1 & $\mathrm{VO}$ \\
\hline Red beetle 0 & $\mathrm{~F}$ & & $\mid 09.00-17.30$ & - & - & - & 1 & $\mathrm{VO}$ \\
\hline
\end{tabular}

Table 5: Effect of different pollination treatment on the yield (in grams) in Gossypiumhirsutum

\begin{tabular}{|c|c|c|c|c|}
\hline Year & Site & $\begin{array}{c}\text { Self } \\
\text { pollination }\end{array}$ & $\begin{array}{c}\text { Open } \\
\text { pollination }\end{array}$ & $\begin{array}{c}\text { Insect } \\
\text { pollination }\end{array}$ \\
\hline First & 1 & 307.87 & 336.58 & 379.57 \\
& 2 & 297.17 & 518.16 & 566.38 \\
Second & 3 & 315.28 & 418.17 & 470.30 \\
& 1 & 311.79 & 455.85 & 569.80 \\
& 2 & 347.12 & 412.16 & 617.37 \\
Third & 3 & 372.64 & 485.69 & 513.11 \\
& 1 & 412.68 & 478.30 & 637.18 \\
& 2 & 378.08 & 435.47 & 530.77 \\
& 3 & 369.33 & 517.50 & 627.24 \\
\hline
\end{tabular}

Volume 5 Issue 2, February 2016 www.ijsr.net 


\section{International Journal of Science and Research (IJSR)}

ISSN (Online): 2319-7064

Index Copernicus Value (2013): 6.14 | Impact Factor (2014): 5.611

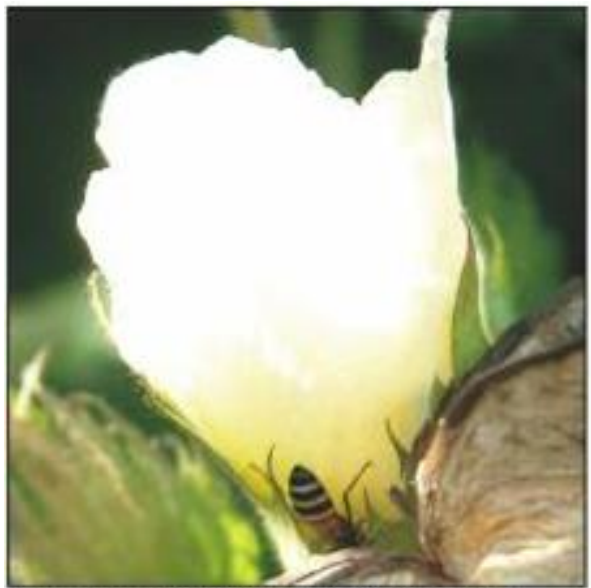

Fig. No.1. A. florea visiting the flower of G. hirsufum

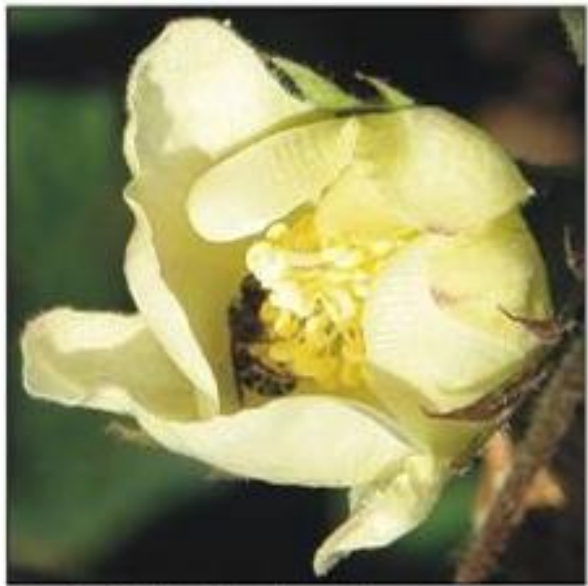

Fig. No.3. Halictidae fly visiting the flower of $G$. hirsutum

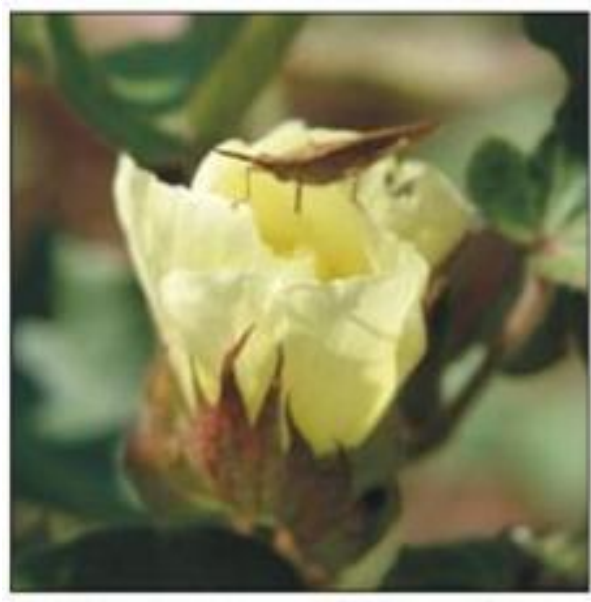

Fig. No.5. Grass hopper visiting the flower of $\mathrm{G}$. hirsutum

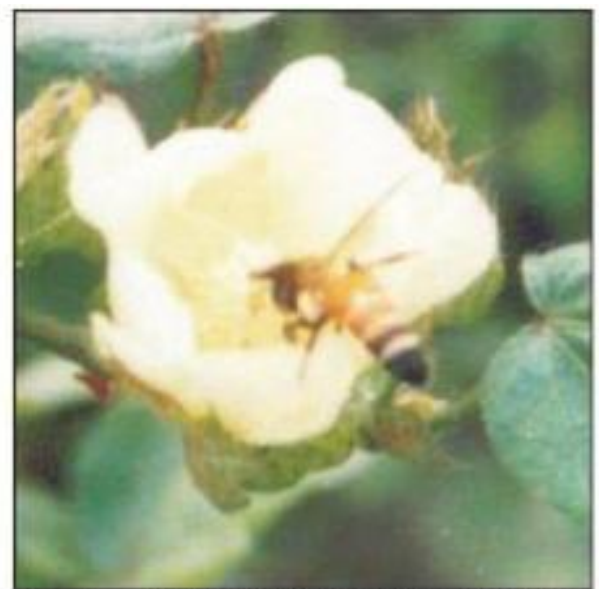

Fig. No.2. A. dorsata foraging on the flower of $G$. hirsutum

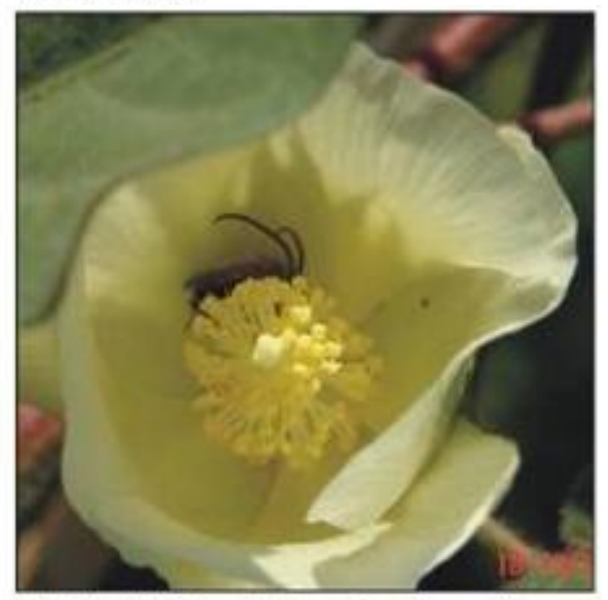

Fig. No.4. Red color bee foraging on the flower of $G$. hirsutum

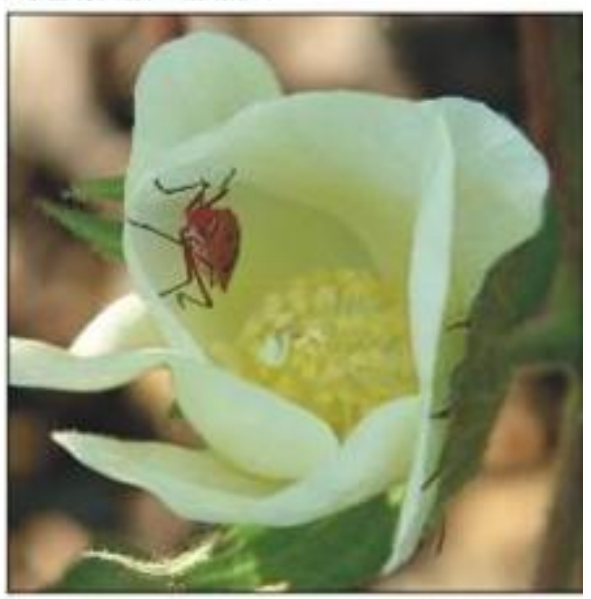

Fig. No.6. Red beetle foraging on the flower of $G$. hirsutum

\section{PLATE-I}

\section{References}

[1] Cruden, R. W. 1977. Pollen-ovule ratios: A conservative indicator of breeding systems in

[2] flowering plants. Evolution 31: $32-46$.
[3] Dafni, A.1992. Pollination Ecology, A Practical Approach, Oxford University Press, New York.

[4] Delaplane, K.S. and Mayer, D.F. 2000. Crop pollination by bees. CABI Pub. Willingford, Oxon, UK.

Volume 5 Issue 2, February 2016

www.ijsr.net 


\section{International Journal of Science and Research (IJSR) \\ ISSN (Online): 2319-7064 \\ Index Copernicus Value (2013): 6.14 | Impact Factor (2014): 5.611}

[5] Deodikar, G. B. and Suryanarayana, M. C. 1977. Pollination in the service of increasing farm production in India. In: , P. K. K. eds., Advances in Pollen Spore Research, 2: 60-82.

[6] Goulson, D. 1999. Foraging strategies of insects for gathering nectar and pollen, and implications for plant ecology and evolution. Perspectives in Plant Ecology, Evolution and Systematics.Vol. 2(2): 185-209.

[7] Goswami V. and Khan M. S. 2014. Impact of honey bee pollination on pod set of Mustard (Brassica juncea L. : Cruciferae) at Pantnagar. The Bioscan 9 (1): 75-78.

[8] Kolreuter, J.G. 1761-1766. VorlaufigerNachdcht von einigen das Geschlecht der PflanzenbetreffendenVersuchen and Beabachten. Leipzig.

[9] Lincoln, R.J., Boxshall, G.A. and Clark, P.F. 1982. A dictionary of ecology, evolution and systematics. Cambridge University Press, New York. Linn Soc., 120: 371-77.

[10]Loken, G. 1942. Ber. Dent. Boten., In: Stanley, R. C. and Linskens, H. F. (ed.) Pollen physiology biochemistry management. Spriner-Verlag, Berlin Heidelber, New York. 6: 299(82).

[11] Mahadevan, V. and Chandy, K.C. 1959. Preliminary studies on the increase in cotton yield due to honeybee pollination. Madras Agric.J. 47: 23-26.

[12] Mailhot D., Marois J., and Wright D. 2007. Arthropod management and applied ecology Species Of Thrips Associated With Cotton Flowers. The Journal of Cotton Science 11:186-198.

[13] Moffett, J.O., Stith, L.S., Burkhart, C. and Shipman, C.W. 1975. Honey bee visits to cotton flowers. Environmental Entomology4(2): 203-206.

[14] MohanaRao G., Nadre, K.R. and Suryanarayana. 1995. Studies on the utility of honey bees on production of foundation seed of cotton CV. NCMHH-20. Indian Bee J. 58 (1): 13-15.

[15]Nabhan, G.P. and Buchmann, S.L. 1997. Pollination services: Biodiversity's direct link to world food stability. G. Daily Pp. 133-150.

[16] Nair, P. K. K. and Rastogi, K. 1963. Pollen production in some allergenic plants. Curr. Sci. 32: 566-567.

[17] Neli S. and Kalita J. 2013. The potential pollinators of Caesalinia crista. The Bioscan 8 (1): 37-41.

[18] Panda, P., Sontakke, B.K. and Sarangi, P.K. 1988. Preliminary studies on the effect of bee (ApisceranaindicaFabr.) Pollination on yield of Sesamum and Niger. Indian Bee J. 50(3): 63-64.

[19]Pleasants, J. M and Wendel, J. F. 2010. Reproductive and Pollination Biology of the Endemic Hawaiian Cotton, Gossypiumtomentosum (Malvaceae) Pacific Science 64(1):45-55.

[20] Preston, R.E. 1986. Pollen-ovule ratios in the Cruciferae. Ame. J. Bot. 73: 1732-1740.

[21] Priti and Sihag, R.C. 1997. Diversity, visitation frequency, foraging behaviour and pollinator efficiency of insect pollinators visiting Cauliflower (Brassica oleracea L. Var. Botrytis cv. Hazipur Local) blossoms. Indian Bee J. 59 (4): 230- 237.

Volume 5 Issue 2, February 2016 www.ijsr.net

Paper ID: NOV161450
[22] Rao, M. and Suryanarayana, M.C. (1979). Effect of honey bee pollination on seed yield in Onion (Allium cepaL.). Ind. Bee. J. 51 (1): 9- 11.

[23] Sidhu, A.S. and Singh, S. (1962). Role of honeybees in cotton production. Indian Cotton Gr. Rev. 16: 33-41.

[24] Sihag, R.C. 1995. Pollination of Asian crop plants. In: Pollination biology: Pollination, plant reproduction and crop seed production (eds.) R.C. Sihag, Rajendra Scientific Pub., Hisar. Pp. 90- 124.

[25] Sinha, S.N. and Chakrabarti, A. K. 1995. Insect pollination and seed yield in onion. In: Pollination Biology: Basic and Applied Principles by Sihag, R. C. (Ed). Rajendra Scientific Publisher Hissar, PP. 167-173.

[26] Stephen, L.B. and Shipman, C.W. 1990. Pollen harvesting rates of Apismellifera on Gossypium (Malvaceae) flowers. J. Kansas Entom. Soc. 63 (1): 92- 100.

[27] Stone, J.L., Thompson, J.D. and Dent-Acosta, S. J. 1995. Assessment of pollen viability in hand-pollination experiments: a review. Ame. J.Bot. 82 (9): 1186-1197.

[28] Tidke, J.A. 2005. Pollination Ecology of Crotalaria sericea Retz.. J. Ind. Bot. Soc. 84:80-84.

[29] Vaissiere, B. E. 1991 Honey bees, Apismellifera L. (Hymenoptera: Apidae), as pollinators of upland cotton, Gossypiumhirsutm L. (Malvaceae) for hybrid seed production Tex. A \& M Univ., College Station - Ph.D. dissert.

[30] Viviane C. P., Fernando A. S., Edison R. S., Karoline R. S. T., Wallyson A. R., Fabio A. A., Sandra M. M., Antonieta N. S. and Carmen S. S. 2014. Importance of bee pollination for cotton production in conventional and organic farms in Brazil. Journal of Pollination Ecology, 13(16): 151-160.

[31] Wheeler, M.J., Franklin-Tong, V.E., and Franklin, F.C.H. 2001. The molecular and genetic basis of pollen-pistil interactions. New Phytol. 151, 565-584. 